\title{
Design and Implementation of Fan Chips as Cooling for Milling Process on Aluminum Alloy 5086 to Increase Tool Life
}

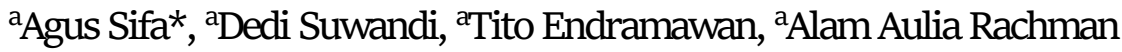 \\ ${ }^{a}$ Mechanical Engineering Department, Politeknik Negeri Indramayu, Indramayu 45252, Indonesia \\ Received 27 January 2021; accepted 31 February 2021
}

\begin{abstract}
In the metal machining process, especially in the milling process, the parameters that affect the quality milling process results are cooling media because it affects the tool life used. This paper aims to determine the performance of using fan chips as the coolant in the dry milling process area. The method used is the computational fluid dynamic (CFD) method and the experimental milling process on a workpiece made from aluminum alloy 5086. In experimental testing using a variation of the milling machine spindle rotation. The simulation test results on the fluid flow character on fan chips with a protector producing a central character with a small area. In contrast, fan chips without a protector make a central character with a broader area. The wind speed data in simulation testing and experimental testing produced the same trend graph. The results of the performance of fan chips after experimented with variations in spindle rotation, cooling process on area occurs when the motor spindle rotates above $1120 \mathrm{Rpm}$ on the fan chips with a protector, and the engine spindle rotates above $770 \mathrm{Rpm}$ on the fan chips without a protector. The effect of fan chips on tool life affects increasing tool life by 8 minutes on installing fan chips with a protector and increasing tool life by 12 minutes on installing fan chips without a protector.
\end{abstract}

\section{KEYWORDS \\ Fan Chips \\ Dry Cutting \\ Milling Process \\ Tool Life \\ Aluminium Alloy}

\section{INTRODUCTION}

Technology development in the manufacturing industry continues to be carried out to maximize product productivity and reduce production costs (Berenji et al., 2019). There is a machining process in the manufacturing industry, and one of the machining processes carried out in the manufacturing industry uses a conventional milling machine. In the milling process, several parameters affect product yield. The parameters that influence are the geometry of the cutting tools used (Yufrizal etl al., 2019), the thickness of the feed, cutting speed (Luo et al., 2017), and cooling (Debnath et al., 2016).

The cutting fluid in the machining process plays a role in cooling the area where there is friction between the cutting tool and the workpiece. Cutting fluid can also be used to clean chips from the cutting process (Sharma et al., 2016). The process area needs to be cooled down, considering that the area that experiences friction between the tool and the workpiece area 
impacts increasing the workpiece temperature. This will result in losses in reduced tool life, and the cooling liquid is also used as a cleaning medium to clean the chips during the cutting process.

In the machining process, it can be done by adding the lubricant or without using the addition of lubricant during the machining process or the dry autting process (Nouari et al., 2003). The dry milling process is carried out without the use of coolant or lubrication during the machining process. The dry milling process can reduce the fluid coolant or lubricant used during the process. Dry milling can reduce cooling fluid waste after use and have an impact on minimizing environmental pollution. Besides reducing the risk to the environment, the dry milling method can also reduce the costs incurred for procuring coolants in the production process using the machining process (Weinert et al., 2004).

Tool Life (T) is a period with a unit of time in minutes, during which the tool or tool angle can maintain its cutting quality before re-indexing it to sharpen the cutting angle of the chisel or chisel (Tschätsch \& Reichelt, 2009). Permanent damage to tools is due to plastic deformation that occurs, where plastic deformation occurs due to heat generated by tool friction (Grzesik, 2017).

A fan Chip is a fan installed at the end of a vertical milling machine that functions to clean the remnants of the milling process without having to clean the chip using a tool (Lang Technik, 2019).

The purpose aims to design and implement fan chips products using a protector and fan chips without a protector on the dry milling process and to know. The performance effect of fan chips can affect tool life-the fan chips product use for a cooling medium on the dry milling process. Where the fan chips mounted on the motor spindle and the fan chips can break the ambient air, which produces cold air, cold air generated by air velocity, and pressure air (Pang, Kalam et al., 2012), cold air can be used as convection cooling to transfer heat in the cutting area (Gupta \& Nayak, 2018), and as a cleaning medium for the rest of the cutting process. The air generated by the fan chip rotating on the motor spindle is used to lower the temperature and also blow the chip from autting.

\section{MATERIALS AND METHODS}

\section{Design Fan Chips}

Installation and design of fan chips in the milling process, both in the roughing process and in the finishing process, the fan chips installation on the milling machine is placed on the spindle, as shown in Figure 1. 


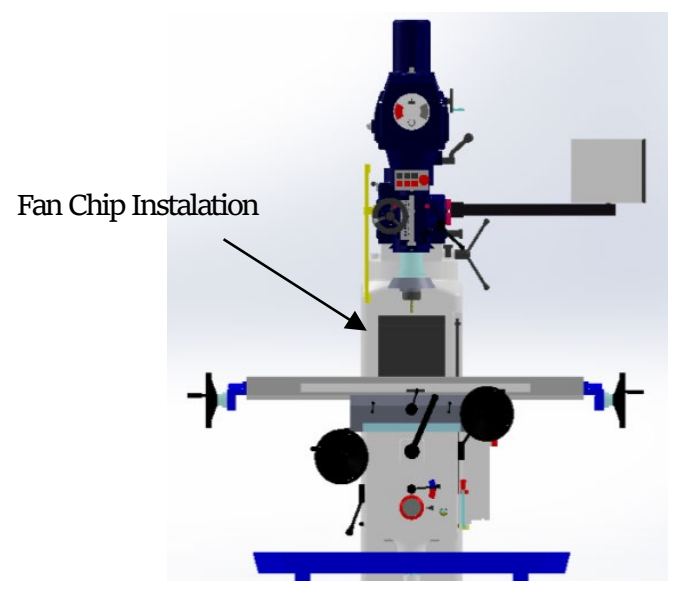

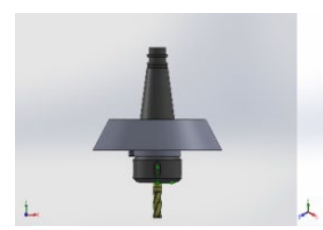

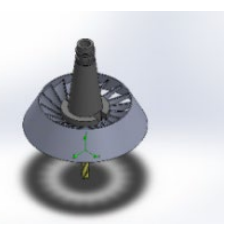

a. Fan Chips With Protector

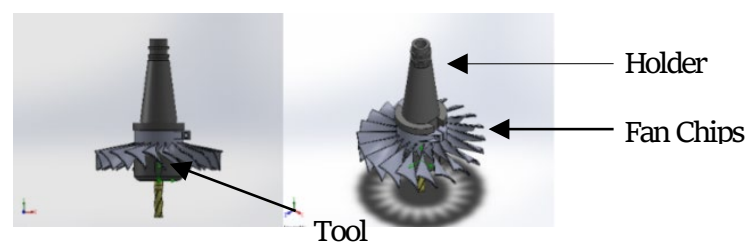

b. Fan Chips Without Protector

Figure 1. Design and fan Chip Installation on conventional machine milling, (a) Fan Chips with Protector, (b) Fan Chips Without Protector

\section{Materials}

Making fan chips prototype using 3D printing techniques. The fan chips prototype was make using Polylactic Acid (PLA) material. PLA material can be used in the 3D printing process as a filler. The Mechanical Properties of PLA are shown in Table 1 (Chacón et al., 2017).

Table 1. Mechanical Properties Polylactic Acid (PLA)

\begin{tabular}{ll}
\hline Mechanical Properties & Polylactic Acid \\
\hline Tensile Strength (MPa) & $15.5-72.2$ \\
Tensile Modulus (GPa) & $2.020-3.550$ \\
Elongation at Break (\%) & $0.5-9.2$ \\
Flextural Strength (MPa) & $52-115.1$ \\
Flextural Modulus (GPa) & $2.392-4.930$ \\
\hline
\end{tabular}

High-Speed Steel (HSS) is a conventional tooling material. All types of HSS contain large amounts of carbon, which reacts with refractory metals to form hard carbides, which increase wear resistance and heat hardness (Grzesik, 2017). The mechanical properties of the HSS material are shown in Table 2 (Azom, 2012), and the mechanical properties of the workpieces are shown in Table 3. (Anonymous, 2020).

Table 2. Mechanical Properties HSS Material

\begin{tabular}{ll}
\hline Mechanical properties & Metric \\
\hline Hardness, Rockwell C (tempered at $1150^{\circ} \mathrm{F}$, quenched at 2200 $\mathrm{F}$ ) & 62 \\
Hardness, Rockwell C (as hardened, quenched at $2200^{\circ} \mathrm{F}$ ) & 65 \\
Compressive yield strength (when tempered at $300^{\circ} \mathrm{F}$ ) & $3250 \mathrm{MPa}$ \\
Izod impact unnotched (when tempered at 300 $\mathrm{F}$ ) & $67 \mathrm{~J}$ \\
Abrasion (loss in $\mathrm{mm}^{3}$, as hardened; ASTM G65) & 25.8 \\
Abrasion (loss in $\mathrm{mm}^{3}$, tempered at $1275^{\circ} \mathrm{F}$; ASTM G65) & 77.7
\end{tabular}


Poisson's ratio

$0.27-0.30$

Elastic modulus

$190-210 \mathrm{GPa}$

Table 3. Mechanical properties Aluminium Alloy 5086

\begin{tabular}{lllll}
\hline Properties & Proof Stress & Tensile Strength & Hardness Brinell & Elongation \\
\hline Metric & $125 \mathrm{Min} \mathrm{MPa}$ & $275-350 \mathrm{MPa}$ & $75 \mathrm{HB}$ & $12 \mathrm{Min} \%$ \\
\hline
\end{tabular}

\section{Methods}

The method used to collect the test data is the simulation test method carried out using software engineering. The experimental testing method, which carried out by testing the application of Fan chips directly. The experimental test method used is to install fan chips on the holder of the milling machine. The fan chips rotate when the motor spindle rotates and produces air to blow the chips remaining from the milling process and reduce the milling process area's temperature. Installation of fan chips on the machine is shown in Figure 2.

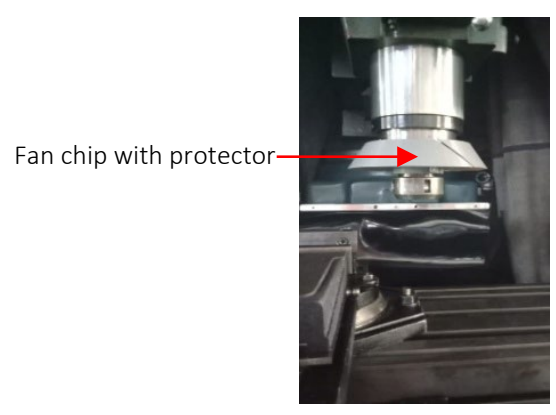

(a)

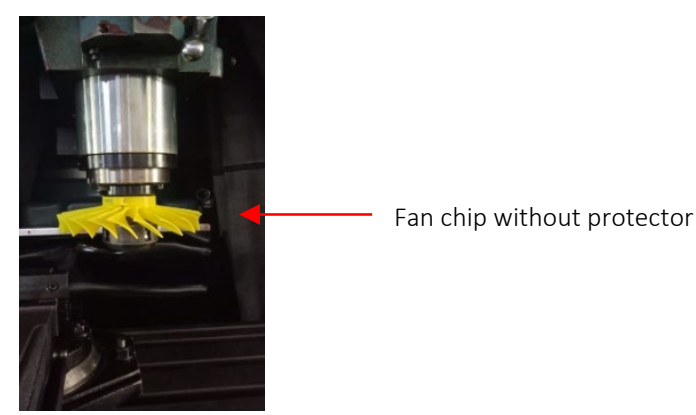

(b)

Figure 2. Fan Chip Installation; (a) Fan Chips with Protector, (b) Fan Chips without Protector

\section{Simulation Testing}

The simulation test carried out is the Computational Fluid Dynamics (CFD) was carried out to determine the phenomenon of fluid flow when the fan chip was operated ( $\mathrm{Hu}, 2012)$. The simulation parameters specified in the CFD simulation are shown in Table 4.

Table 4. CFD Simulation Testing Parameters

\begin{tabular}{ll}
\hline Description & Parameter \\
\hline Analysis Type & External Rotation \\
Fluid Type & Air \\
Flow Type & Laminar and Turbulent \\
Initial temperature conditions & $30^{\circ} \mathrm{C}$ \\
Spindle Rotation Speed & 480 Rpm, 770 Rpm, 1120 Rpm and 1800 Rpm \\
\hline
\end{tabular}




\section{AGUS SIFA ET.AL}

The initial temperature condition is at $30^{\circ} \mathrm{C}$ because of the average value obtained when taking ambient temperature data before testing. Variations in the machine's spindle rotation speed adjust to the milling machine's conditions at testing.

\section{Experimental Testing}

Experimental testing is carried out to collect wind speed data generated by fan chips and changes in temperature in the milling process area. Tests were carried out using a vertical milling machine with the specifications shown in Table 5 .

Table 5. Machine Specification

\begin{tabular}{ll}
\hline Brand & PaoFong \\
\hline Manufactured & PaoFongIndustry., LTD \\
Model & PF-5S \\
Serial Number & 165004 \\
Date Production & 2016 \\
Voltage & 380 Volt \\
\hline
\end{tabular}

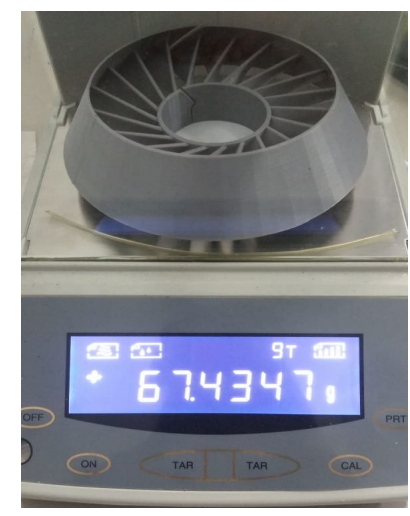

(a)

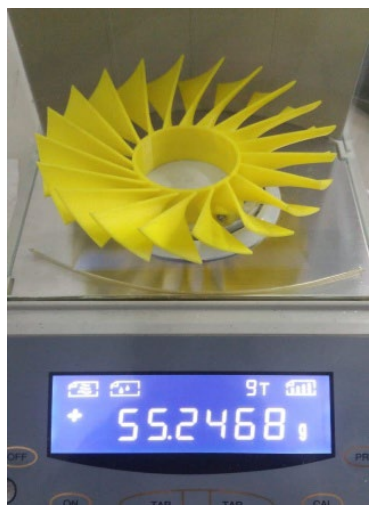

(b)

Figure 3. Fan Chips Weight, (a) Fan Chips with protector, (b) Fan Chips without protector

Figure 3 shows the difference in weight between fan chips with protectors and fan chips without a protector, where fan chips with protectors weigh 67,435 grams, and fan chips' weight without a protector 55, 347 grams.

\section{RESULTS AND DISCUSSION}

\section{Computing Fluid Dynamic}

From the simulation test that has been carried out, the results of the wind fluid flow are shown in Figure 4 


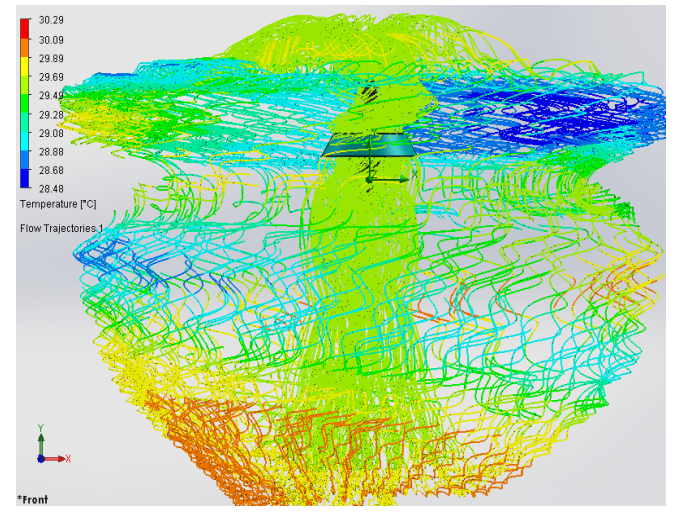

(a)

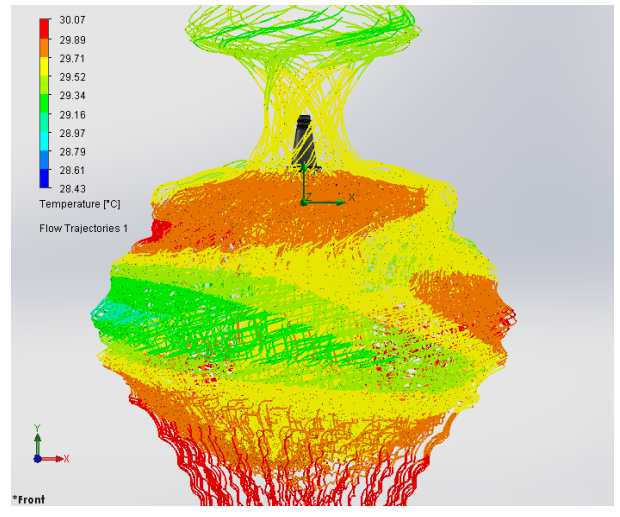

(b)

Figure 4. Fluid Flow of Fan Chips; (a) Fluid Flow of Fan Chips with Protector, (b) Fluid Flow of Fan Chips without Protector (b)

The fluid flow that occurs in each fan chip has different characteristics. On fan chips with protector, the fan-produced is concentrated in the center but with a small area. The fan chips without a protector made airflow is centered on and has a larger size than fan chips with a protector. The fan chip without a protector affects the fan chip's performance to reduce the process area's temperature and blow off the milling process's scraps. Simulation testing uses flow simulation, the simulation design made according to fan chips installation conditions on the Milling machine. Fan Chips are mounting on the motor tool holder, and it can be velocity data generated by the fan chip is shown in Table 6 and Table 7.

\begin{tabular}{ll}
\multicolumn{2}{c}{ Table 6. Wind speed Fan Chips with protector } \\
\hline Rpm & Velocity (m/s) \\
\hline 480 & 1.3 \\
770 & 1.8 \\
1120 & 3.1 \\
1800 & 4.4 \\
\hline
\end{tabular}

Table 7. Wind speed Fan Chips without protector

\begin{tabular}{ll}
\hline Rpm & Velocity $(\mathrm{m} / \mathrm{s})$ \\
\hline 480 & 1.3 \\
770 & 1.9 \\
1120 & 4.2 \\
1800 & 6.6 \\
\hline
\end{tabular}

\section{Experiments}

The experimental test is to measure changes in the temperature of the milling process area and the wind speed produced by fan chips. The measuring instruments used are an anemometer and infrared thermometer.

Testing fan chips with a protector to determine the effect on process temperature changes and clean the scrap from the milling process. Data on temperature changes in the milling process area by applying a fan chip with a protector, shown in Figure 5 . 


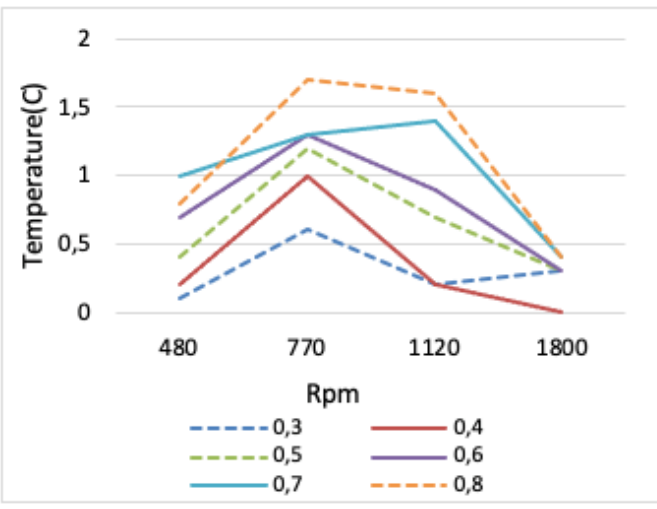

(a)

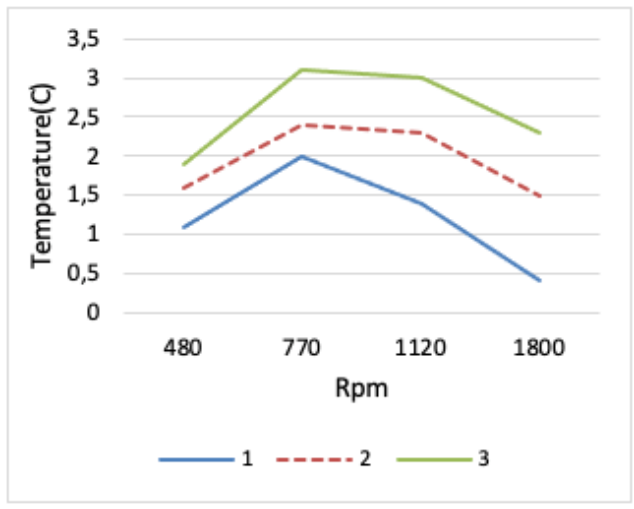

(b)

Figure 5. Temperature of Fan Chip without protector; (a) Finishing and (b) Roughing

The temperature changes that occur in the installation of fan chips with the protector, the temperature increase still occurs at each variation of cutting depth. However, when the spindle rotates above $1120 \mathrm{rpm}$, the milling process area's temperature decreases in autting depth variations. So, it can be said that the effect of fan chips with the protector works to reduce the temperature of the process area when the motor spindle rotates above $1120 \mathrm{rpm}$.

Installation of fan chips without protectors is also carried out in the same way as testing fan chips with a protector. The experimental aims to determine the comparison of the two fan chips made. Data on temperature changes in the process area occur when applying fan chips without a protector, shown in Figure 6.

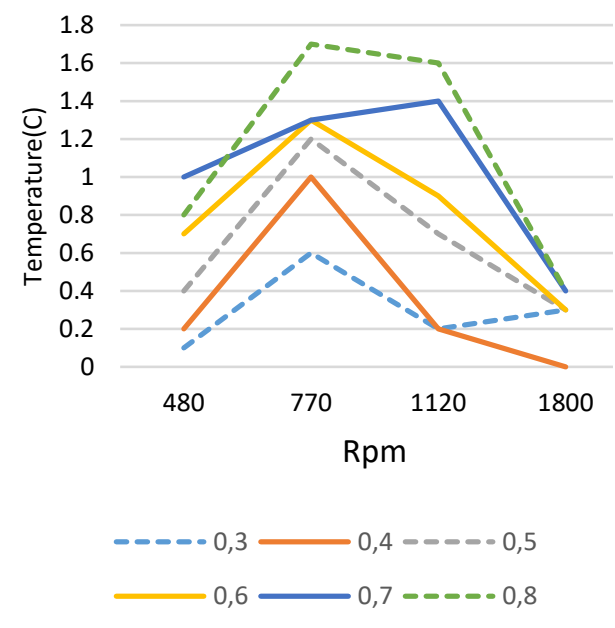

(a)

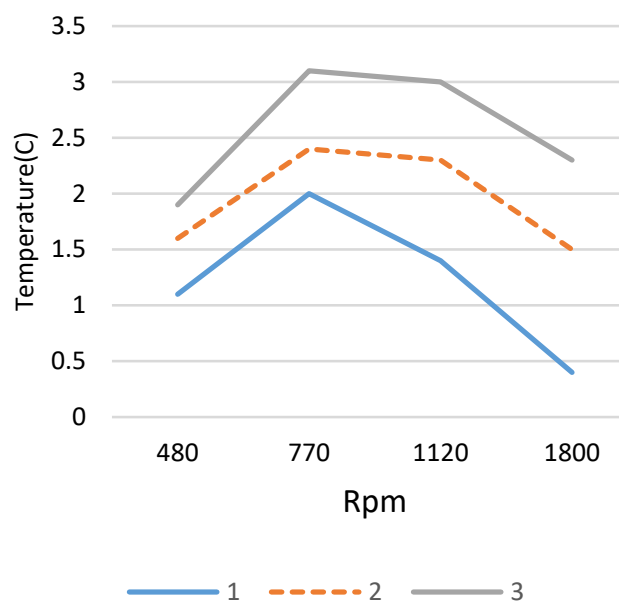

(b)

Figure 6. The temperature of fan chip without protector; (a) Finishing process and (b)Roughing process

In Figure 6, the test results obtained by the temperature difference between the temperature results in the tool edge and the environment. The temperature changes that occur when installing fan chips without a protector affected the temperature increase at every cutting depth variation. However, when the spindle rotates above $1120 \mathrm{rpm}$, the milling process decreases the 
temperature in all cutting depth variations. So, that fan chips' effect with the protector works to reduce the temperature of the process area when the motor spindle rotates above $1120 \mathrm{rpm}$, as shown in Figure 6(a).

Installation of fan chips without a protector is doing the same as testing fan chips with a protector. The implementation of a fan chip to determine the comparison of the two fan chips made. Data on temperature changes in the process area that occur in fan chips' application without a protector, shown in Figure 6(b).

The temperature changes in installing fan chips without a protector show a decrease in the processing temperature when the spindle rotates above $770 \mathrm{rpm}$. The process temperature can drop when the motor spindle rotation is above $770 \mathrm{Rpm}$ due to the wind generated by the fan chips. The comparison of the velocity produced by each fan chip, shown in Figure 6.

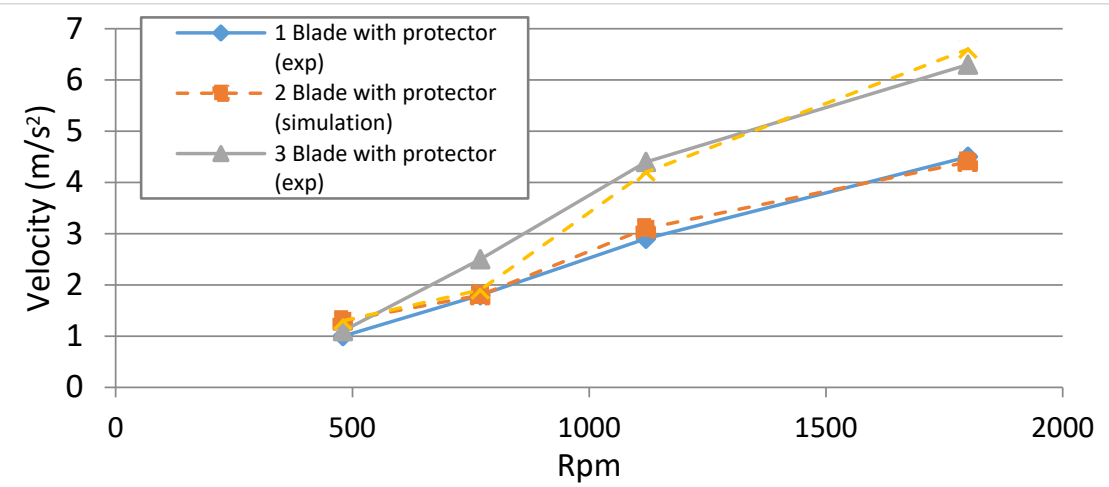

Figure 7. Fan Chips Wind Speed

Figure 7 is the velocity data generated by the fan chip in simulation testing and experimental testing. The test data on wind speed generated by simulation and experimental testing have the same trend line. The resulting line graph shows the same trending from the wind speed comparison data obtained in simulation testing and experimental testing. The velocity generated from fan chips affects the power to blow scraps for the milling machining process's remainder.

\section{Power and Wind Force of Fan Chips}

Fan Chips installed on the Milling machine produce air that blows the scrap/chips leftover from the autting. From the wind, it can be seen that the power is generated using the following equation 1 (Rhett Allain, 2012).

$$
P_{\text {Wind }}=\frac{\rho \cdot A \cdot v^{3}}{4}
$$

Where: $\mathrm{P}=$ Power Wind (Watt), $\rho=$ Density of air $(\mathrm{kg} / \mathrm{m} 3), \mathrm{A}=$ Fan Chips area (m2), $\mathrm{v}=$ Wind velocity $(\mathrm{m} / \mathrm{s})$, From the above equation in determining wind power, the area of the Fan Chips area and the speed generated by Fan Chips are variables that affect the value of the 
wind power generated. The wind force can be calculated using the following equation(Rhett Allain, 2012).

$$
F_{\text {air }}=\frac{\rho \cdot A \cdot v^{2}}{2}
$$

Where: $\rho$ = Density of air (kg/m3), A = Fan Chips area(m2), $v=$ Wind velocity $(\mathrm{m} / \mathrm{s}), \mathrm{F}=$ Wind force $(\mathrm{Kg})$, wind power data of each fan chips is shown in Figure 8.

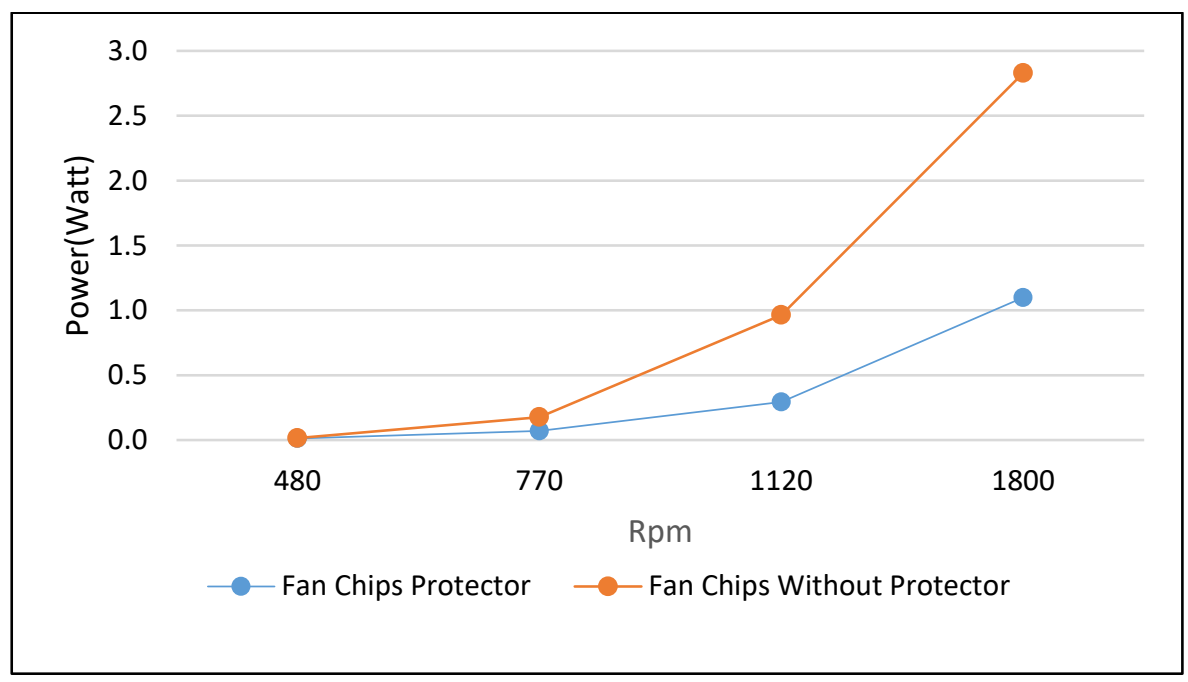

Figure 8. Wind Power Fan Chips

The wind-blowing force of fan chips blew chips leftover from the cut. The wind gust, which the wind blowing force calculated use equation 2, shown in Figure 9.

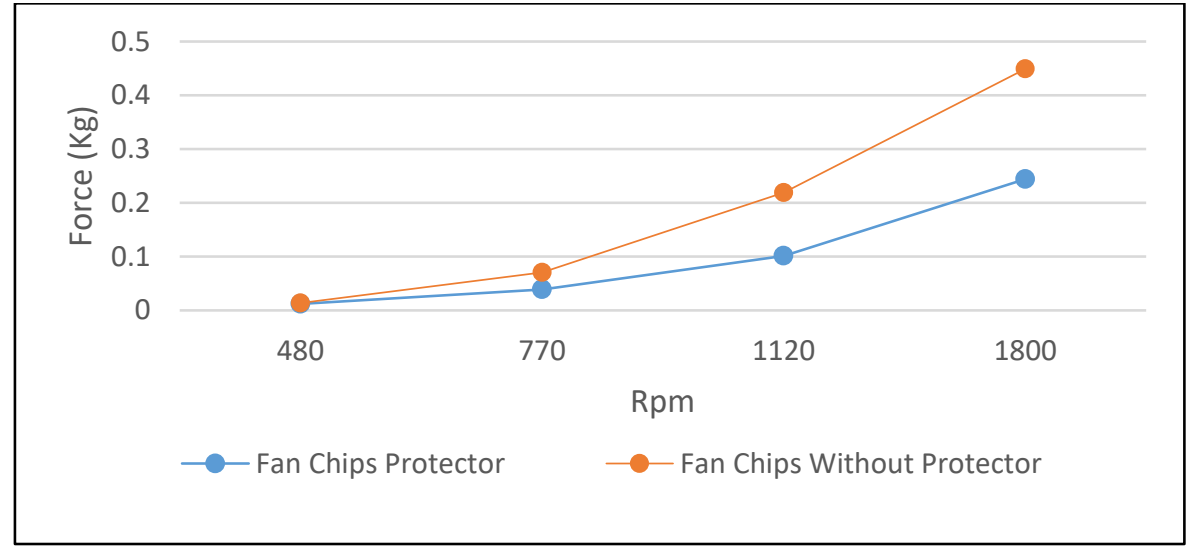

Figure 9. Wind Blowing Force

In experimental testing by cutting the workpiece, Fan Chip is not fully working optimally. Fan Chips with Protector can blow the remaining chips when the motor spindle rotates above 1120 rpm. Meanwhile, Fan Chips Without Protector works to blow chips, performs to blow the 
remaining chips when the motor spindle rotates above $770 \mathrm{rpm}$, that the minimum force to blow the remaining chips is with a wind blowing force above $0.07 \mathrm{Kg}$. If it is less than this value, Fan Chips are not maximal in blowing the remaining chips. So that fan chips without protector have better performance than fan chips with protector.

\section{Tool Life Prediction}

Cutting tool life can be predicted using the Taylor equation. The general Taylor equation is written as follows (Johansson et al., 2017):

$$
\text { v. } T^{n}=C
$$

Where: $\mathrm{v}$ is autting speed, $\mathrm{T}$ is Tool Life, $\mathrm{n}$ is exponential tool life, and $\mathrm{C}$ is Constant. However, the Taylor equation, in general, has not been influenced by temperature in predicting tool life, so the Taylor equation is expanded by adding a temperature variable in predicting Tool Life which is written as follows (Kovac et al., 2019):

$$
\begin{gathered}
T=C_{v} \cdot\left(\frac{C_{\theta}}{\theta_{m}}\right)^{\frac{Z}{P}} \\
\theta_{m}=C_{\theta} \cdot v^{P}
\end{gathered}
$$

Where: $\mathrm{T}$ is Tool life, $\theta_{m}$ is temperature, $\mathrm{C}_{\mathrm{v}}, \mathrm{C}_{\theta}$ is constant, dan $\mathrm{Z}, \mathrm{P}$ is exponential. From the temperature data obtained experimentally, the tool life predictions are shown in Figures 10(a) and Figure 10(b).

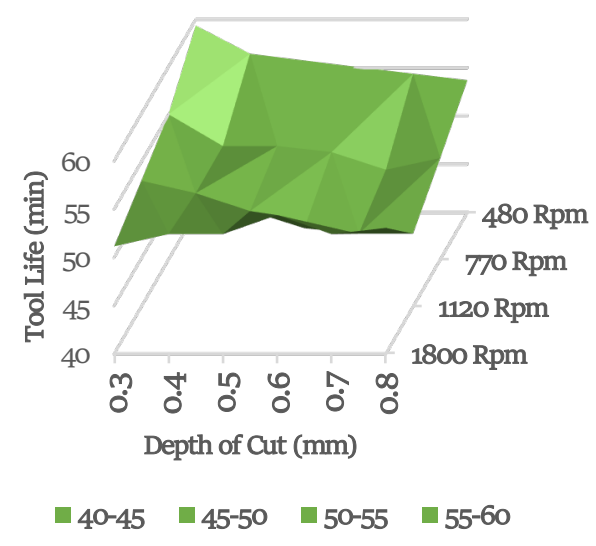

(a)

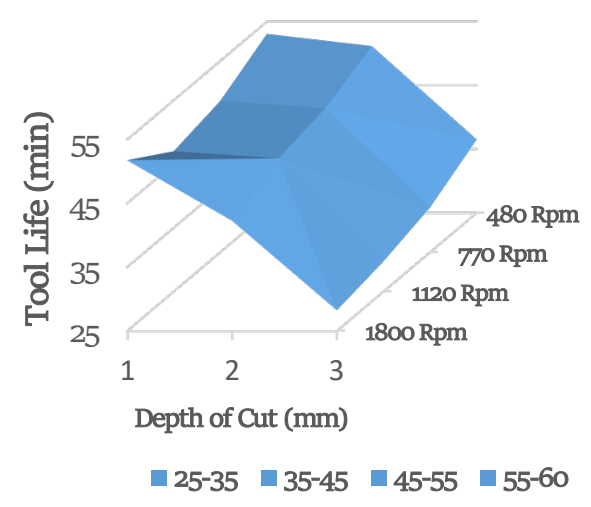

(b)

Figure 10. Predict Tool Life Without Installing Fan Chips; (a) Finishing process and (b) Roughing process

In figure 10, Tool Life without Fan Chips installed has decreased lifetime, and the tool has increased temperature due to friction with the workpiece, which reduces the tool life used (Parida 
\& Maity, 2018). The Maximum value of Tool Life HSS does not reach 100 minutes (Debapriya M, 2020).

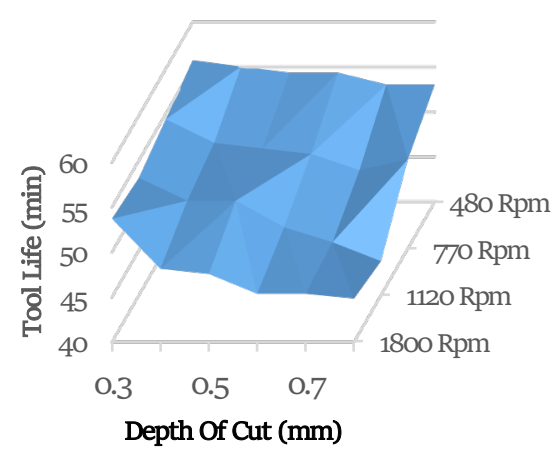

- 40-45 - 45-50 $\quad$ 50-55 $\quad$ 55-60

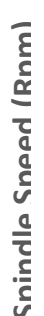

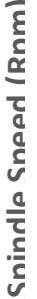

(a)

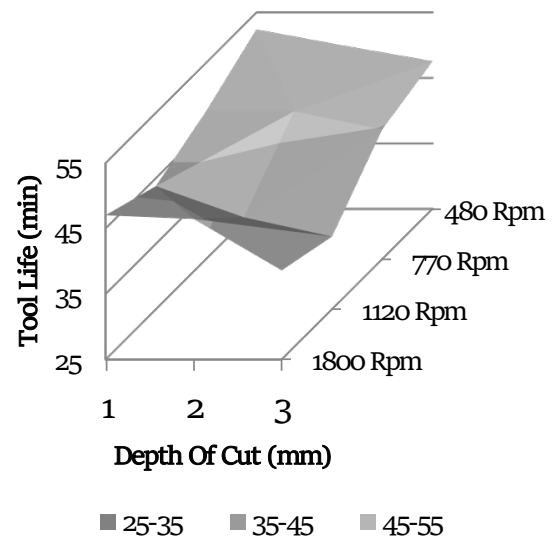

(b)

Figure 11. Tool Life Prediction used Fan Chips with Protector; (a) Finishing process and (b) Roughing process

From Figure 11, tool life has decreased when installing fan chips with protector because the increasing rotation and cutting speed will decrease the value of tool life (Akbar et al., 2018). However, when the motor spindle rotates above $1120 \mathrm{rpm}$, the value of tool life increases because fan chips work to lower the process area's temperature. So that with the installation of fan chips with a protector, it can extend the life of the tool used. The increase in the value of tool life on fan chips with protector installation is \pm 38 minutes at $1800 \mathrm{Rpm}$ motor spindle rotation with an infeed depth of $3 \mathrm{~mm}$. Before installing fan chips, the tool life value is \pm 28 minutes with the same parameters.

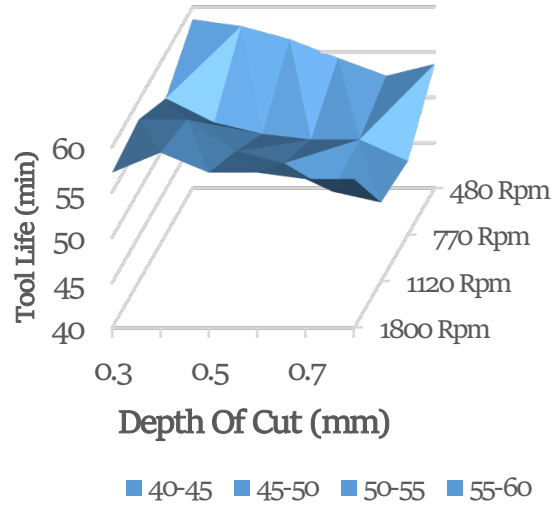

(a)

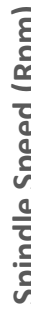

(b)

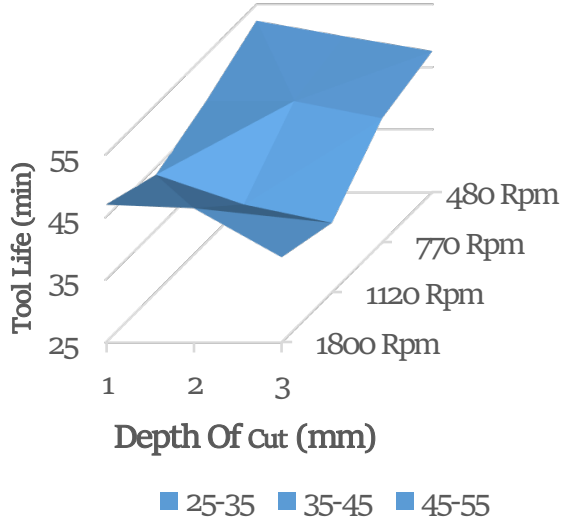

Figure 12. Tool Life Prediction used Fan Chips Without Protector; (a) Finishing process and (b) Roughing process 
From Figure 11, tool life has decreased when installing fan chips with protector because the increasing rotation and cutting speed will decrease the value of tool life (Akbar et al., 2018). However, when the motor spindle rotates above $1120 \mathrm{rpm}$, the value of tool life increases because fan chips work to lower the process area's temperature. So that with the installation of fan chips with a protector, it can extend the life of the tool used. The increase in the value of tool life on fan chips with protector installation is \pm 38 minutes at 1800 Rpm motor spindle rotation with an infeed depth of $3 \mathrm{~mm}$. Before installing fan chips, the tool life value is \pm 28 minutes with the same parameters.

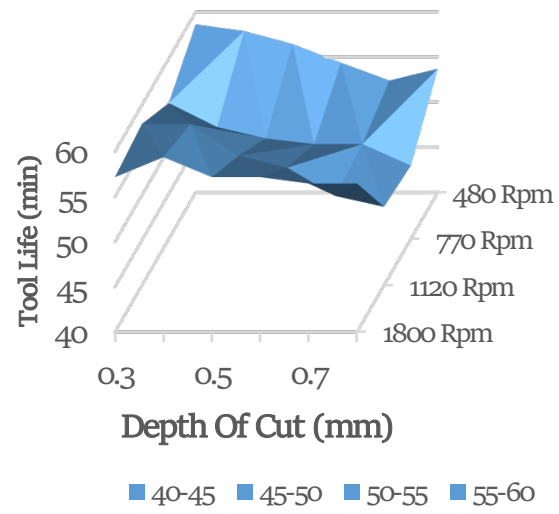

(a)

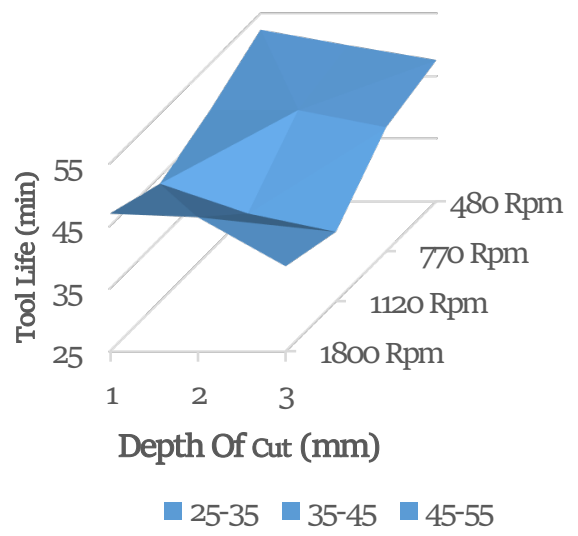

(b)

Figure 12. Tool Life Prediction used Fan Chips Without Protector; (a) Finishing process and (b) Roughing

From Figure 12, tool life has decreased when the motor spindle rotates below the rotation speed of $770 \mathrm{rpm}$, but when the motor speed is above $770 \mathrm{rpm}$, tool life has increased. This is because at this speed fan chips without a protector works to reduce the temperature of the process area, which affects the re-increase of tool life. The increase in tool life value that occurs is \pm 44 minutes on the motor spindle rotation of $1800 \mathrm{rpm}$ with an ingestion depth of $3 \mathrm{~mm}$, while before installing fan chips, the tool life value is \pm 28 minutes with the same parameters.

\section{CONCLUSION}

From the simulation tests carried out, the fluid flow generated by the fan chips with the protector produces a concentrated wind character but with a small area. Meanwhile, the fan chips without protection have a centralized wind character with a broader scope.

The experiment results show the fan chips affected by the temperature tool. The effect changed the temperature in the cutting process area. The fan chips with a protector can reduce the temperature when the motor spindle rotates above $1120 \mathrm{rpm}$. Fan chips without a protector can reduce the cutting process area's temperature when the motor spindle rotates above $770 \mathrm{rpm}$. 
Tool life prediction has to determine the effect of installing a fan chip on tool Life. Theimpact of fan chips with the protector on tool life was found to extend tool life by 8 minutes. The effect of fan chips without a protector on tool life was seen to extend tool life by 12 minutes.

\section{ACKNOWLEDGEMENTS}

The author would like to thank the Ministry of Research and Technology, Indramayu State Polytechnic, and the Department of Mechanical Engineering, Indramayu State Polytechnic.

\section{REFERENCES}

Akbar, A. A., Shwaish, R. R., \& Hadi, N. D. (2018). Study the Effect of Cutting Parameters on Temperature Distribution and Tool Life During Turning Stainless Steel 316L. Al-Khwarizmi Engineering Journal, 14(3), 112-122.

Anonymous. (2020). Aluminium Alloy 5086 Square Bar. Retrieved from Aluminium Alloy 5086 Square Bar: Retrieved Juli 30, 2020, from website: https://www.maxsteels.com/aluminium-alloy5086-square-bar-supplier-exporter.html

Azom. (2012). M2 Molybdenum High Speed Tool Steel (UNS T11302). Retrieved Juli 27, 2020, from website: https://www.azom.com/article.aspx?ArticleID=6174

Berenji, K. R., Karagüzel, U., Özlü, E., \& Budak, E. (2019). Effects of turn-milling conditions on chip formation and surface finish. CIRP Annals, 68(1), 113-116.

Chacón, J. M., Caminero, M. A., García-Plaza, E., \& Núnez, P. J. (2017). Additive manufacturing of PLA structures using fused deposition modelling: Effect of process parameters on mechanical properties and their optimal selection. Materials \& Design, 124, 143-157.

Debapriya M. (n.d.). Tool Life: Meaning, Measurement and Expectancy. Retrieved July 27, 2020, from website: https://www.yourarticlelibrary.com/metallurgy/tool-life-meaning-measurementand-expectancy/96151

Debnath, S., Reddy, M. M., \& Yi, Q. S. (2016). Influence of cutting fluid conditions and cutting parameters on surface roughness and tool wear in turning process using Taguchi method. Measurement, 78, 111-119.

Grzesik, W. (2017). In Chapter Four - Cutting Tool Materials Advanced Machining Processes of Metallic Materials (Second Edition) (pp. 35-63).

Gupta, N., \& Nayak, A. K. (2018). Performance evaluation of coolant air with buoyancy in a parallelogrammic mixed displacement ventilated system. International Journal of Mechanical Sciences, 149, 38-53.

Hu, H. H. (2012). In Chapter 10 - Computational Fluid Dynamics Fluid Mechanics (pp. 421-472). Elsevier.

Johansson, D., Hägglund, S., Bushlya, V., \& Ståhl, J.-E. (2017). Assessment of commonly used tool life models in metal cutting. Procedia Manufacturing, 11, 602-609.

Kovac, P., Gostimirovic, M., Rodic, D., \& Savkovic, B. (2019). Using the temperature method for the prediction of tool life in sustainable production. Measurement, 133, 320-327.

Lang Technik. (2019). Chip Fan Clean-Tec. Retrieved July 14, 2020, from website: https://www.langtechnik.de/en/produkte/gruppen/50

Luo, M., Wang, J., Wu, B., \& Zhang, D. (2017). Effects of cutting parameters on tool insert wear in end milling of titanium alloy Ti6Al4V. Chinese Journal of Mechanical Engineering, 3O(1), 53-59.

Nouari, M., List, G., Girot, F., \& Coupard, D. (2003). Experimental analysis and optimisation of tool wear in dry machining of aluminium alloys. Wear, 255(7-12), 1359-1368. 
Pang, S. C., Kalam, M. A., Masjuki, H. H., \& Hazrat, M. A. (2012). A review on air flow and coolant flow circuit in vehicles' cooling system. International Journal of Heat and Mass Transfer, 55(23-24), 6295-6306.

Parida, A. K., \& Maity, K. (2018). Experimental investigation on tool life and chip morphology in hot machining of Monel-400. Engineering Science and Technology, an International Journal, 21(3), 371-379.

Rhett Allain. (2012). Modeling The Force From The Fan. Retrieved Agustus 06, 2020, from https://www.wired.com/2012/og/modeling-the-force-from-a-fan/

Sharma, A. K., Tiwari, A. K., \& Dixit, A. R. (2016). Effects of Minimum Quantity Lubrication (MQL) in machining processes using conventional and nanofluid based cutting fluids: A comprehensive review. Journal of Cleaner Production, 127, 1-18.

Tschätsch, H., \& Reichelt, A. (2009). Cutting fluids (coolants and lubricants). In Applied Machining Technology (pp. 349-352). Springer.

Weinert, K., Inasaki, I., Sutherland, J. W., \& Wakabayashi, T. (2004). Dry machining and minimum quantity lubrication. CIRP Annals, 53(2), 511-537.

Yufrizal, A., Indrawan, E., Helmi, N., Aziz, A., \& Putra, Y. A. (2019). Pengaruh Sudut Potong dan Kecepatan Putaran Spindel Terhadap Kekasaran Permukaan pada Proses Bubut Mild Steel ST 37. Invotek: Jurnal Inovasi Vokasional Dan Teknologi, 19(2), 29-36. 